\title{
Teaching Video NeuroImages: Posterior territory stroke with parahippocampal involvement
}

\author{
A neglected cause of neglect
}

Noortje A.M.M. Maaijwee, MD, PhD, Patricia Dreier, MD, Stephan Bohlhalter, MD, and Thomas Nyffeler, MD Neurology ${ }^{\circledR}$ 2018;90:e2181. doi:10.1212/WNL.0000000000005687
Correspondence

Dr. Maaijwee

noortje.maaijwee@luks.ch

Figure Brain MRI

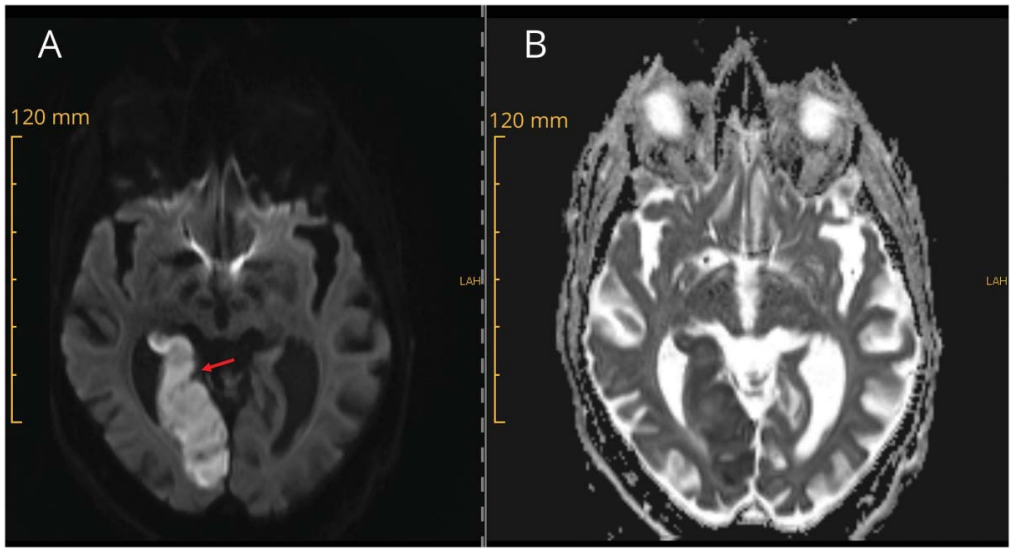

(A) Diffusion-weighted imaging sequence and (B) apparent diffusion coefficient sequence show a stroke in the right posterior cerebral artery territory involving the parahippocampal gyrus (see arrow).

An 87-year-old patient presented with a stroke in the right posterior territory (figure), with visual neglect, which was initially thought to be left homonymous hemianopia. The tip of the occipital lobe was spared, however, and therefore complete hemianopia was not to be expected. With a posterior stroke, neglect can easily be overlooked, although it is common in posterior strokes, when the parahippocampal gyrus is involved. ${ }^{1}$ The 2 deficits can be tested for separately by turning the body of the patient to the left and the head to the right, because the neglect is body-centered. ${ }^{2}$ (video).

\section{Author contributions}

Dr. Dreier: acquisition of data, interpretation of symptoms, critical revision of manuscript. Dr. Maaijwee: acquisition of data, interpretation of symptoms, preparation of manuscript. Prof. Nyffeler: interpretation of symptoms, critical revision of manuscript, patient supervision. Prof. Bohlhalter: interpretation of symptoms, critical revision of manuscript, preparation of video, patient supervision.

\section{Study funding}

No targeted funding reported.

\section{Disclosure}

The authors report no disclosures relevant to the manuscript. Go to Neurology.org/N for full disclosures.

\section{References}

1. Mort DJ, Malhotra P, Mannan SK, et al. The anatomy of visual neglect. Brain 2003;126:1986-1997.

2. Nyffeler T, Paladini RE, Hopfner S, et al. Contralesional trunk rotation dissociates real vs. pseudo-visual field defects due to visual neglect in stroke patients. Front Neurol 2017;8:411.

\section{MORE ONLINE}

\section{$\rightarrow$ Video}

$\rightarrow$ Teaching slides

links.lww.com/WNL/A558

From Neurocenter (N.A.M.M.M., P.D., S.B., T.N.), Lucerne State Hospital; and Perception and Eye Movement Laboratory (T.N.), Departments of Neurology and Clinical Research, Inselspital, Bern University Hospital and University of Bern, Switzerland.

Go to Neurology.org/N for full disclosures. Funding information and disclosures deemed relevant by the authors, if any, are provided at the end of the article. 


\section{Neurology}

\section{Teaching Video NeuroImages: Posterior territory stroke with parahippocampal involvement: A neglected cause of neglect}

Noortje A.M.M. Maaijwee, Patricia Dreier, Stephan Bohlhalter, et al.

Neurology 2018;90; 2181

DOI 10.1212/WNL.0000000000005687

\section{This information is current as of June 11, 2018}

\section{Updated Information \&} Services

References

Subspecialty Collections

Permissions \& Licensing

Reprints including high resolution figures, can be found at: http://n.neurology.org/content/90/24/e2181.full

This article cites 2 articles, 0 of which you can access for free at: http://n.neurology.org/content/90/24/e2181.full\#ref-list-1

This article, along with others on similar topics, appears in the following collection(s):

\section{All Cerebrovascular disease/Stroke}

http://n.neurology.org/cgi/collection/all_cerebrovascular_disease_strok e

\section{Clinical neurology examination}

http://n.neurology.org/cgi/collection/clinical_neurology_examination Neglect

http://n.neurology.org/cgi/collection/neglect

Information about reproducing this article in parts (figures,tables) or in its entirety can be found online at:

http://www.neurology.org/about/about_the_journal\#permissions

Information about ordering reprints can be found online:

http://n.neurology.org/subscribers/advertise

Neurology ${ }^{\circledR}$ is the official journal of the American Academy of Neurology. Published continuously since 1951, it is now a weekly with 48 issues per year. Copyright @ 2018 American Academy of Neurology. All rights reserved. Print ISSN: 0028-3878. Online ISSN: 1526-632X.

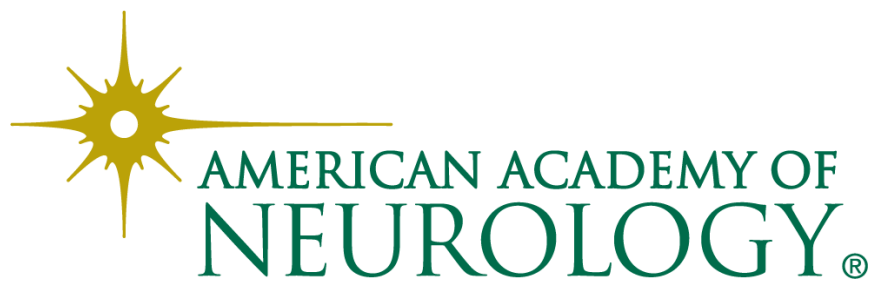

